\title{
Pengaruh Kompensasi Dan Kepuasan Kerja Terhadap Kinerja Karyawan Pada PT Winsen Kencana Perkasa
}

\section{Toni}

Universitas Putera Batam

pb170910040@upbatam.ac.id

\author{
Mauli siagian \\ Universitas Putera \\ Batam \\ maulisgn@gmail.com
}

\begin{abstract}
This study aims to determine the effect of (X1) compensation and (X2) job satisfaction on $(Y)$ employee performance at PT Winsen Kencana Perkasa by using this 130 response saturation sampling technique. The data collection method used a questionnaire. This study uses multiple regression test results showing that (X1) compensation and (X2) job satisfaction have a positive effect on $(Y)$ employee performance based on regression results and with the value of $R$ Square. Based on statistical data, the indicators in this study are valid and reliable variables. Hypothesis testing using the $t$ test shows that (X1) compensation and (X2) job satisfaction are proven to have a significant effect on $(Y)$ employee performance. Then through the $F$ test it can be seen that the variable (X1) compensation and (X2) job satisfaction simultaneously must have an effect on employee performance variables with $F$ count greater than $F$ table
\end{abstract}

\section{Keywords Compensation, Job satisfaction, Employee performance}

\section{PEndahuluan}

Di era sekarang ini, segala aspek kehidupan manusia memiliki banyak pengaruh. Kita dapat melihat bahwa semakin banyak perusahaan yang bermunculan, termasuk perusahaan nasional, internasional, kecil, menengah dan besar. Munculnya perusahaan bar u terus menerus membuat persaingan semakin ketat sehinggu perusahaan yang tidak lagi kompetitif akan hilang dan terlupakan. Jadi dalam dunia kerja saat ini, memaksa manusia untuk memiliki sumber daya yang terampil dan kompeten. Terlepas dari apakah itu perusahaan publik ataupun merupakan suatu perusahaan swasta, tentu terdapat sumber daya manusia yang memiliki kompetensi di perusahaan. Sumber daya manusia yang kompeten tersebut mampu untuk memainkan peran yang sangat penting. Hal ini diakibatkan karena kompensasi yang baik dan kepuasan kerja karyawan mampu membawa pengaruh positif terhadap perusahaan. Dapat dikatakan bahwa kompensasi paling berdampak bagi karyawan karena dapat menimbulkan pemahaman tersendiri yang 
berpengaruh terhadap kepuasan kerja karyawan.

Kompensasi penting karena kompensasi membantu organisasi mencapai keberhasilan perusahaan, bisa berupa dengan upah finansial langsung ataupun finansial tidak langsung yang diterima oleh karyawan digunakan sebagai kompensasi bagi perusahaan. Kompensasi yang sesuai akan menentukan apakah karyawan akan tetap atau meninggalkan tempat kerja. Pernyataan ini di dukung oleh (Kilvin \& Siagian, 2020) menyatakan bahwa bentuk pembagian kompensasi yang memadai dan tepat sasaran diharapkan dapat mendatangkan rasa puas oleh pegawai sehingga mempengaruhi tingkat kinerjanya. Masih oleh (Siagian \& Defrianti, 2018) kompensasi yang baik dan tepat akan memuaskan karyawan dan meningkatkan kinerjanya. Dengan kompensasi yang cukup untuk berhasil menyelesaikan pekerjaan, maka karyawan akan bersemangat untuk melakukan pekerjaan yang diberikan kepadanya dan berusaha untuk memecahkan masalah yang muncul.

Antar individu pada dasarnya mempunyai perbedaan tingkat kepuasan dimana bergantung kepada sistem penilaian yang berlaku untuk seluruh individu. Kepuasan kerja ialah respons emosional yang menyeluruh. Respons emosional tersebut yakni hasil dari harapan, permintaan, keinginan, dan dorongan karyawan untuk pekerjaannya, dan terkait dengan kesadaran karyawan akan realitas, yang menyebabkan respons emosional dalam bentuk kesenangan, kepuasan atau ketidakpuasan. Kepuasan kerja karyawan serta kesenangannya dalam menjalankan pekerjaan atau tugasnya dianggap sebagai faktor yang krusial sebab bisa dihubungkan langsung dengan kinerja karyawan. Pernyataan ini di dukung oleh (Siagian, 2017) kepuasan dalam melakukan suatu perkejaan oleh karyawan akan memotivasi karyawan, sehingga masalah ini perlu diatasi dengan baik terlebih pada dasarnya hal tersebut akan mampu mencerminkan bagaimana kinerja dari karyawan itu sendiri. Artinya, setiap karyawan dalam suatu perusahaan akan mampu meningkatkan kinerjanya jika terdapat suatu kepuasan tersendiri ketika melakukan pekerjaan.

Selain itu, dalam mendorong karyawan agar mampu bekerja lebih baik lagi dan meningkatkan semangat dalam bekerja maka karyawan harus merasa puas dengan pekerjaan yang dimilikinya. Keadaan tersebut mampu membantu perusahaan dalam rangka mencapai suatu tujuan yang diinginkan oleh perusahaan. Terlebih, dalam kepuasan kerja sendiri akan mampu memberikan peningkatan dalam kinerja karyawan bukan hanya pada satu sisi tapi karyawan secara keseluruhan. Sebagaimana pernyataan tersebut telah didukung oleh (Yudha, 2018) bahwa kepuasan karyawan dalam berkerja menjadi sebuah elekmen yang sangat penting dalam kaitannya untuk menentukan keberhasilan suatu perusahaan.

Kinerja sangatlah penting dalam suatu pekerjaan yang di mana perusahaan menginginkan karyawannya berkerja dengan baik agar dapat mencapai hasil kerja yang memuaskan, jika kinerja seorang karyawan baik maka keberhasilan dalam mencapai tujuan akan mudah tercapai. Pernyataan ini di dukung oleh (Perkasa, Mariah, \& Ajis, 2019) kinerja atau prestasi kerja sendiri merupakan hal yang mengacu pada ukuran kualitas dan ukuran kuantitas dari pekerjaan dimana pekerjaan tersebut telah dilakukan oleh seorang karyawan sebagaimana sesuai dengan kewajiban dan tanggungjawab yang telah diberikan kepada karyawan tersebut.

Permasalahan yang dialami oleh PT Winsen Kencana Perkasa antara lain tidak tercapainya kinerja, laba perusahaan mengalami penurunan dan tidak sesuai target yang ditetapkan, juga ada beberapa penyebab masalah kinerja antara lain dalam pemberian kompensasi 
khususnya pemberian tujangan dan insentif yang kurang merata kadangkalanya memicu kecemburuan sosial antar karyawan. Selain itu karyawan mengeluh merasa tidak nyaman bekerja karena kebijakan dari atasan yang terus berubah sehingga menjadikannya bingung dalam menjalankan perintah atasan.

\section{LANDASAN \\ Teori Kinerja \\ Kinerja karyawan}

Menurut (Shinta \& Siagian, 2020) kinerja karyawan adalah suatu penilaian dari hasil atas pekerjaan individu dan tim perusahaan untuk melaksanakan tugas pokok yang berlaku dalam suatu organisasi, sedangkan Menurut (Latief, Syanrdiansah, \& Safwan, 2019) kinerja mengacu pada ukuran kuantitas dan ukuran kualitas atas pekerjaan yang dilakukan oleh para karyawan yang seseusi sesuai dengan tugas dan tanggungjawab sebagaimana telah diberikan kepadanya.

\section{Indikator Kinerja}

Menurut (Latief et al., 2019), terdapat empat buah indicator yang mampu menjadi suatu acuan dalam kaitannya untuk melakukan pengukuran kinerja kepada karyawan atau pengukuran kinerja kepada para pegawai perusahaan, sebagaimana hal tersebut dapat dilihat berikut:

1. Kualitas kerja yang merupakan suatu kemampuan karyawan untuk melakukan hal yang sebaiknya dapat mereka lakukan.

2. Kuantitas kerja merupakan ukuran tentang waktu atau seberrapa lama individu dalam melakukan pekerjaan di perusahaan selama satu hari sehingga menghasilkan seberapa banyak pekerjaan yang dapat diselesaikan. Selain itu dapat dikatakan lamanya pegawai melakukan pekerjaannya selama satu hari (biasanya 8 jam per hari) untuk menghasilkan produk barang ataupun jasa dalam perusahaan. Dalam kuantitas kerja tersebut sendiri dapat dilihat juga dari tingkat kecepatan para karyawan dalam melakukan pekerjaannya sesuai dengan jobdesk masing-masing.

3. Prestasi kerja merupakan sebuah ukuran mengenai sejauh mana karyawan dapat menyelesaikan suatu pekerjaan yang menjadi tanggugjawabnya dimana pekerjaan tersebut dilakukan secara akurat tanpa terjadinya suatu kesalahan tertentu.

4. Tanggung jawab kerja merupakan suatu hal yang mengacu pada tanggungjawab dan suatu kewajiban seorang karyawan dalam kaitannya untuk melaksanakan ataupun melakukan suatu pekerjaan yang telah dibebankan atau diberikan oleh perusahaan kepadanya selama bekerja diperusahaan tersebut.

\section{Kompensasi}

Sesuai pemaparan dari (Rohaeni 2016) bahwa yang dimaksud kompensasi yakni pemberian dengan financial kepada karyawan sebagai balas jasa atas pekerjaannya serta sebagai motivasi untuk menjalankan berbagai aktivitas ke depannya. Menurut Kilvin \& Siagian, (2020) Kompensasi adalah bentuk pencapaian akan prestasi yang diberikan perusahaan dalam bentuk uang serta produk dan layanan, sehingga karyawan akan merasa dijunjung tinggi di tempat kerja. Kondisi ini akan mendorong pekerja untuk memberikan imbal jasa dalam bentuk kepatuhan 
terhadap aturan pekerjaan dan akuntabilitas untuk pencapaian perusahaan.

\section{Indikator Kompensasi}

Menurut (Heryenzus \& Laia, 2018) telah mengemukakan bahwasanya secara umum terdapat beberapa indicator yang membahas mengenai kompensasi sebagaimana berikut:

1. Gaji yang merupakan sebuah gambaran kompensasi berupa pendapatan yang diperoleh karyawan atas kontribusinya dan upayanya mencapai tujuan perusahaan

2. Upah insentif ekonomi dibayarkan langsung kepada karyawan berdasarkan jam kerja, jmlah barang yang diproduksi atau jumlah layanan yang diberikan.

3. Imbalan dibayarkan langsung kepada para karyawan yang dilatarbelakangi oleh kinerjanya yang telah melebihi suatu standar yang ditentukan oleh perusahaan.

4. Bentuk subsidi dapat berupa pemotongan pajak pada saat jatuh tempo, gabungan dana perusahaan, keterkaitan antara pension dan asuransi, serta bentuk pembayaran yang dapat dibayarkan setiap bulan, sekali atau gabungan keduanya.

\section{Kepuasan Kerja}

(Yudha 2018) memaparkan, kepuasan kerja ialah sebuah sikap individu terhadap pekerjaan sebagai ketidaksamaan antara besar ganjaran yang pekerja terima dengan besaran yang diyakininya harus diterima. Sedangkan menurut (Adha, Wandi, \& Yanto Susanto 2019) menyatakan, kepuasan kerja pegawai bisa merasakan pekerjaannya tersebut tidak menyenangkan atau menyenangkan untuk dilakukan. Sedangkan (Latief, Syardiansah, \& Sarfwan 2019), kepuasan kerja ialah sikap emosional yang mencintai serta menyenangkan atas pekerjaan yang dikerjakannya. Sikap tersebut dicerminkan oleh prestasi kerja, kedisiplinan, serta moral kerja. Kepuasan kerja bisa seseorang nikmati di luar pekerjaan, dalam pekerjaan, maupun gabungan keduanya

\section{Indikator Kepuasan Kerja}

Menurut (Yudha, 2018) indikator-indikator yang terkait dengan kepuasan kerja dapat dijelaskan sebagaimana berikut ini :

1. Pekerjaan itu sendiri (Work Itself), setiap suatu pekerjaan yang sangat membutuhkan suatu keahlian tertentu dalam bidangnya yang dikuasai dan bidang yang dibutuhkan oleh peruisahaan Terlepas dari apakah pekerjaan yang dilakukan tersebut merupakan pekerjaan yang sulit atau tidak dan orang membutuhkan pengetahuannya di tempat kerja, itu akan meningkatkan atau menurunkan kepuasan kerja.

2. Atasan (Supervision) menjadi salah satu indikator dalam kaitannya dengan kepuasan kerja. Hal tersebut diakibatkan karena atasan yang baik artinya atas tersebut mampu dan bersedia menghargai hasil kerja bawahannya yaitu karyawan yang bekerja di perusahaan. Keadaan tersebut dianggap bahwan bahwa selain sebagai atasan dan pemimpin namun dapat menjadi sahabat yang mampu untuk meningkatkan kinerjanya.

3. Teman sekerja (Workers), rekan kerja berhubungan antara atasan atau pemimpin dengan karyawan lain baik dalam bidang ataupun jenis pekerjaan yang sama atau berbeda.

4. Promosi (Promotion), merupakan suatu indikator yang berhubungan atau memiliki keterkaitan dengan kepuasan kerja. Hal ini dikarenakan promoasi sangat terkait dengan memunculkan 
kemungkinan naiknya karir seorang karyawan pada jenjang yang lebih tinggi sehingga karyawan berusaha untuk meningkatkan kinerjanya.

5. Gaji/Upah (Pay), merupakan faktor yang memenuhi kebutuhan karyawan dianggap memadai atau tidak memadai

\section{Pengembangan Hipotesis \\ Hubungan kompensasi dengan kinerja karyawan}

(Perkasa et al., 2019) mengemukakan bahwa kompensasi yang diberikan suatu perusahaan ataupun lembaga kepada karyawan yang bekerja akan memiliki suatu berpengaruh bernilai positif dan pengaruh tersebut merupakan suatu pengaruh signifikan. Hal ini menunjukkan jika kompensasi yang diberikan mengalami suatu peningkatan maka kinerja karyawan juga akan selatas dalam kaitannya mengalami peningkatan. Berdasarkan hasil dari penelitian terdahulu, maka dalam penelitian yang dilakukan ini sendiri dapat diajukan hipotesis sebagai berikut:

H1: kompensasi memiliki pengaruh positif terhadap kinerja karyawan.

\section{Hubungan kepuasan kerja dengan kinerja karyawan}

(Perkasa et al, 2019), hubungan antara kepuasan dalam melakukan pekerjaan dan kinerja akan lebih tepat untuk disebut sebagai suatu mitos manajemen. Keadaan tersebut terjadi karena sulitnya untuk menentukan arah dari suatu hubungan kausual diantara kedua hal tersebut. Akan tetapi, melihat berbagai penelitian yang pernah dilakukan sebelumnya telah menunjukkan dan menemukan bukti jika suatu organisasi dengan memiliki tingkat kepuasan karuawan lebih tinggih lebih banyak organisasi yang lebih rendah lebih efektif. Berdasarkan hasil dari penelitian terdahulu, maka dapat diajukan suatu hipotesis penelitian sebagaimana berikut:

H2: kepuasan kerja karyawan akan memiliki pengaruh yang bernilai positif terhadap kinerja karyawan.

\section{Hubungan kompensasi dan kepuasan kerja dengan kinerja karyawan}

Penilaian dari adanya suatu pengaruh secara bersama-sama atau suatu pengaruh yang disebut sebagai simultan dari semua variabel independen yang meliputi kompensasi kerja dan variabel Kepuasan Kerja terhadap kinerja karyawan PT Winsen Kencana Perkasa yang dimana hasil dalam penelitian yang telah dilakukan meliti menunjukkan adanya suatu pengaruh variabel tersebut terhadap kinerja karyawan. Mengingat hubungan ini secara simultan sehingga baik kompensasi yang diterima oleh karyawan ataupun kepuasan kerja telah menunjukkan hasil jika dalam penelitian ini memberikan suatu pengaruh terhadap kinerja karyawan yang bekerja pada PT. Winsen Kencana. Keadaan demikian mampu memunculkan hipotesis sebagai berikut:

H3: Kepuasan kerja memiliki suatu pengaruh yang bernilai positif terhadap kinerja pegawai.

\section{METODE PENELITIAN}

Penelitian ini dimulai bulan september 2020 hingga febuari 2021 di PT Winsen Kencana Perkasa yang belokasi di kompleks batam center indah blok c no.7-8 dan objek yang di teliti adalah karyawan PT Winsen Kencana Perkasa, variabel dalam penelitian ini terdiri dari kompensai dan kepuasan kerja sebagai variabel bebas(X), dan kepuasan kerja sebagai variabel terikat(Y). Metode 
penelitian yang pergunakan yakni analisis deskriptif dimana diaplikasikan dalam kuantitatif, yakni model dimana pelaksanaannya melalui pengumpulan keperluan informasi lebih dari serta selanjutnya menganalisis serta memprosesnya guna memahami ataupun merangkum masalah ataupun kondisi. populasi yang dipergunakan yakni pegawai tetap dari 130 individu dalam PT Winsen Kencana Perkasa. Teknik yang dipergunakan untuk sampling yakni sampling jenuh, yakni sebuah teknik dalam mengambil sample dimana seluruh populasi dipergunakan selaku sampel semua anggota populasi digunakan sebagai sampel

\section{HASIL DAN PEMBAHASAN}

Tabel 1. Hasil Pengujian Validitas Instrumen

\begin{tabular}{ccccc}
\hline Variabel & Item & r hitung & r tabel & \multirow{2}{*}{ Kesimpulan } \\
\hline \multirow{4}{*}{ Kompensasi } & X1.1 & 0,719 & 0,1723 & \\
& X1.2 & 0,76 & 0,1723 & \\
& X1.3 & 0,779 & 0,1723 & Valid \\
& X1.4 & 0,628 & 0,1723 & \\
& X1.5 & 0,555 & 0,1723 & \\
\hline
\end{tabular}

(Sumber: Hasil Output SPSS 25, 2020)

Tabel 1. Hasil Pengujian Validitas

\begin{tabular}{ccccc}
\hline Variabel & $\begin{array}{c}\text { Item } \\
\text { Pernyataan }\end{array}$ & r hitung & r tabel & Kesimpulan \\
\hline \multirow{4}{*}{ Kepuasan Kerja } & X1.1 & 0,692 & 0,1723 & \\
& X1.2 & 0,747 & 0,1723 & \\
& X1.3 & 0,694 & 0,1723 & Valid \\
& X1.4 & 0,674 & 0,1723 & \\
& X1.6 & 0,622 & 0,1723 & \\
\hline
\end{tabular}

(Sumber: Hasil Output SPSS 25, 2020)

Tabel 1. Hasil Uji Validitas

\begin{tabular}{ccccc}
\hline Variabel & $\begin{array}{c}\text { Item } \\
\text { Pernyataan }\end{array}$ & r Hitung & r Tabel & Kesimpulan \\
& & & & \\
\hline \multirow{2}{*}{ Kinerja Karyawan } & Y1 & 0,855 & 0,1723 & \multirow{2}{*}{ Valid } \\
\hline
\end{tabular}




\begin{tabular}{rrr} 
Y1 & 0,747 & 0,1723 \\
Y1 & 0,794 & 0,1723 \\
Y1 & 0,653 & 0,1723 \\
Y1 & 0,592 & 0,1723 \\
\hline
\end{tabular}

(Sumber: Hasil Output SPSS 25, 2020)

Berdasarkan hasil output menggunakan alat uji statistik tepatnya SPSS Versi 25 menunjukkan nilai pengujian valitias baik $r$ hitung maupun $r$ tabel. Tabel tersebut telah memperlihatkan jika variabel kompensasi, variabel mengenai kepuasan kerja lebih besar dibandingkan dengan nilai $\mathrm{r}$ tabel senilai $0,1723(\mathrm{df}=130)$. Dengan demikian, seluruh pernyataan pada variabel dinyatakan valid.

Tabel 2. Hasil Uji Reliabilitas

\begin{tabular}{lll}
\hline Variabel & Cronbach'S Alpha & N of Items \\
\hline Kompensasi (X1) & 0,762 & 6 \\
Kepuasan Kerja (X2) & 0,705 & 6 \\
Kinerja Karyawan (Y) & 0,808 & 6 \\
\hline
\end{tabular}

(Sumber: Hasil Output SPSS 25, 2020)

Berdasarkan hasil tabel 2 yang merupakan output SPSS versi 25 telah menunjukkan jika nilai dari Cronbach's alpha memperlihatkan nilai yang sebesar 0,762. Kemudian pada variabel variabel kepuasan kerja memiliki nilai Cronbach's alpha sebesar 0,705, kemudian pada variabel kinerja karyawan sendiri telah memiliki nilai Cronbach's alpha sebesar 0,808. Berdasarkan atas penelitian yangmana telah dilakukan dan memberikan hasil bahwa baik dari nilai Cronbach's alpha variabel kompensasi kerja yang diberikan perusahaan (PT Winsen Kencana Perkasa), kepuasan kerja karyawan perusahaan (PT Winsen Kencana Perkasa) dan kinerja karyawan dengan nilai $>0,60$. Jadi sebagaimana nilai tersebut maka variabel penelitian dapat dinyatakan reliabel.

Tabel 3 Hasil Uji Normalitas One-Sample Kolmogorov-Smirnov Test

\begin{tabular}{|c|c|c|}
\hline \multirow{3}{*}{$\begin{array}{l}\text { N } \\
\text { Normal Parameters }\end{array}$} & & 130 \\
\hline & Mean & .0000000 \\
\hline & $\begin{array}{l}\text { Std. } \\
\text { Deviation }\end{array}$ & 3.05286694 \\
\hline Most Extreme & Absolute & .051 \\
\hline \multirow[t]{2}{*}{ Differences } & Positive & .051 \\
\hline & Negative & -.027 \\
\hline \multicolumn{2}{|c|}{$\begin{array}{l}\text { Kolmogorov-Smirnov Z } \\
\text { A symn Sig (2-tailed) }\end{array}$} & .051 \\
\hline Asymp. Sig. (2-tailed) & & 200 \\
\hline
\end{tabular}


(Sumber: Hasil Output SPSS 25, 2020)

Berdasarkan hasil tabel 3 yangmana merupakan hasil penelitian output SPSS versi 25 yang dilakukan pada PT Winsen Kencana Perkasa menunjukkan bahwa nilai redidual dalam penelitian ini telah terdistribusi secara normal. Keadaan demikian telah ditunjukkan dari nilai signifikansi sebesar $0,20>0,05$. Maka melihat hal tersebut dapat disimpulkan jika penelitian ini telah lulus dalam uji normalitas menggunakan One-Sample Kolmogorov Smirnov Test.

Tabel 4 Hasil Uji Multikolinearitas

\begin{tabular}{llrr}
\hline & & \multicolumn{2}{c}{ Collinearity } \\
Statistics \\
Model & Tolerance & VIF \\
\hline 1 & Kompensasi & .648 & 1.544 \\
& Kepuasan Kerja & .648 & 1.544 \\
\hline
\end{tabular}

(Sumber: Hasil Output SPSS 25, 2020)

Hasil beberapa uji linear ditunjukkan pada tabel 4 dimana setiap variabel bebas meliputi variabel kompensasi yang diberikan perusahaan (X1) dan kepuasan kerja karyawan (X2) adalah sama yaitu senilai 0,648 . Nilai tersebut merupakan nilai yang mana tidak kurang dari $(<) 0,10$ serta menunjukkan juga jika nilai VIF dalam output SPSS pada setiap variabel bebas juga sama yaitu senilai 1,544 dan nilai ini tidak lebih besar dari 10. Dengan demikian dapat disimpulkan bahwa dalam penelitian yang dilakukan pada PT. Winsen Kencana Perkasa tidak terdapat multikolinieritas antar variabel bebas.

Tabel 5 Hasil Uji Heteroskedastisitas

\begin{tabular}{|c|c|c|c|c|c|c|}
\hline \multirow{4}{*}{1} & & $\mathrm{~B}$ & Std. Error & Beta & & \\
\hline & (Constant) & 1.376 & 1.176 & & 1.171 & .244 \\
\hline & Kompensasi & .072 & .057 & 139 & 1.274 & .205 \\
\hline & Kepuasan Kerja & -.026 & .056 & -.052 & -.472 & .638 \\
\hline
\end{tabular}

(Sumber: Hasil Output SPSS 25, 2020)

Peryataan tabel di atas dari hasil analisis mengindikasikan bahwasannya nilai pada variabel kompensasi (X1) nilai signifikansinya melebihi 0,05 atau 0,205 , dan variabel kepuasan kerja (X2) nilai signifikansinya melebihi 0,05 atau 0,638. Konklusinya yaitu dalam model tersebut tidak mengalami gejala heteroskdastisitas.

Tabel 6 Hasil Uji Analisis Regresi Linear Berganda

\begin{tabular}{|c|c|c|c|c|c|c|}
\hline & & B & Std. Error & Beta & & \\
\hline \multirow[t]{3}{*}{1} & (Constant) & 3.782 & 2.027 & & 1.866 & .064 \\
\hline & Kompensasi & .230 & .098 & 199 & 2.355 & .020 \\
\hline & Kepuasan Kerja & .579 & .097 & .505 & 5.988 & .000 \\
\hline
\end{tabular}


(Sumber: Hasil Output SPSS 25, 2020)

Berdasarkan tabel 6 di atas bisa didapatkan persamaan regresi linear berganda sebagai berikut: $\mathrm{Y}=3.782+0,230 \mathrm{X} 1+0,579 \mathrm{X} 2$

Nilai konstanta sebesar 3.782, artinya nilai kinerja karyawan adalah 3.782. Nilai koefisien regresi untuk variabel Kompensasi yaitu menunjukkan nilai atau angka sebesar 0.230. Kemudian, nilai tersebut juga memiliki tanda yang posisitf sehingga keadaan demikian mampu dikatakan bahwa pengaruhnya meruapakan pengasuh yang positif dari kompensasi yang diberikan perusahaan terhadap kinerja karyawan. Jika terjadi suatu peningkatan dari variabel kompensasi yang diberikan perusahaan sebesar 1\% maka kinerja karyawan PT Winsen Kencana Perkasa akan meningkat atau mengalami kenaikan sebesar 0,230 dan peningkatan kearah positif. Nilai koefisien dari pengujian regresi menggunakan SPSS 25 untuk variabel kepuasan kerja karyawan menunjukkan hasil output adalah sebesar 0.579 . Kemudian, hasil output tersebut bernilai positif sehingga dapat dikatakan jika terjadi suatu perubahan meningkatnya kepuasan kerja karyawan PT. Winsen Kencana Perkasa sebesar $1 \%$ maka akan mampu memberikan peningkatan sebesar $0,579 \%$ kepada kinerja karyawan pada perusahaan

Tabel 7 Hasil Uji Determinasi

\begin{tabular}{lrrrr}
\hline Model & R & R Square & $\begin{array}{c}\text { Adjusted R } \\
\text { Square }\end{array}$ & $\begin{array}{l}\text { Std. Error of } \\
\text { the Estimate }\end{array}$ \\
\hline 1 & $.644^{\mathrm{a}}$ & .414 & \multicolumn{4}{c}{.405} & 3.077 \\
\hline
\end{tabular}

(Sumber: Hasil Output SPSS 25, 2020)

Berdasarkan hasil output menggunakan alat uji statistik SPSS 25 sebagaimana ditunjukkan oleh tabel 7 telah memperlihatkan bahwa nilai dari Adjusted R Square adalah sebesar 0,405 atau jika dipersentasekan sendiri menjadi sebesar 41,4\%. Keadaan demikian dapat dikatakan jika kinerja karyawan pada PT. Winsen Kencana Perkasa telah dipengaruhi oleh kompensasi yang diberikan perusahaan maupun kepuasan kerja karyawan itu sendiri. Pengaruh tersebut bernilai sebesar $41,4 \%$ sedangkan $58,6 \%$ sendiri telah dipengaruhi oleh variabel lain dimana variabel lain tersebut tidak dijelaskan dalam penelitian ini.

Tabel 8 Hasil Uji t

\begin{tabular}{|c|c|c|c|c|c|c|}
\hline & & B & Std. Error & Beta & & \\
\hline \multirow[t]{3}{*}{1} & (Constant) & 3.782 & 2.027 & & 1 & 398 \\
\hline & Kompensasi & .230 & .098 & 199 & 5.189 & .000 \\
\hline & Kepuasan Kerja & .579 & .097 & .505 & 2.828 & .005 \\
\hline
\end{tabular}

(Sumber : Hasil Output dari SPSS 25, 2020)

Hasil pengujian menggunakan uji t dapat dijelaskan sebagaimana berikut:

1. Variabel kompensasi (X1) dengan nilai $t$ hitung menunjukkan nilai sebesar $(2,355)>t$ tabel $(1,978)$ dan signifikansi $0,002<0,05$. Jadi, kompensasi berdampak positif serta 
signifikan terhadap kinerja karyawan.dengan demikian adanya kompensasi yang adil dan sesuai dengan beban pekerjaan akan meningkatkan kinerja karyawan. Dari hasil penalitian ini di dukung oleh (Putri \& Ardiana 2019) menyimpulkan, kompensasi memberi pengaruh positif dan signifikan terhadap kinerja karyawan. Begitu juga menurut (Siama, Herminawati, \& Ruslan 2017) kompensasi memberi pengaruh yang positif serta signifikan pada kinerja karayawan.

2. Variabel kepuasan kerja (X2) ditunjukkan dengan t hitung dimana nilai tersebut sebesar $(5,988)>t$ tabel $(1,978)$ dan nilai signifikansi dimana nilai tersebut sebesar $0,000<0,05$. Jadi, dengan demikian pekerjaan memerlukan kerjasama dalam membentuk hubungan dengan atasan dan rekan kerja kepuasan kerja akan meningkan. penelitian ini sejalan dengan penelitian yang dilakukan oleh (Laia, Umi, \& Adi 2019) yang menyimpulkan bahwa kepuasan kerja berpengaruh positif terhadap kinerja karyawan. Begitu juga menurut (Widyawati, Adnyana, \& Mustika 2019) kompensasi memberi pengaruh signifikan positif dan signifikan kepuasan kerja karyawan.

Tabel 9 Hasil Uji F

\begin{tabular}{llrrrrr}
\hline Model & & \multicolumn{1}{c}{ Sum of } & \multicolumn{2}{c}{ Mean } \\
Squares & \multicolumn{1}{l}{ df } & \multicolumn{1}{c}{ Square } & \multicolumn{1}{c}{ F } & \multicolumn{1}{c}{ Sig. } \\
\hline 1 & Regression & 849,994 & 2 & 424,972 & 44,891 & $.000^{\mathrm{b}}$ \\
& Residual & 1202,280 & 127 & 9,467 & & \\
& Total & 2052,223 & 129 & & & \\
\hline
\end{tabular}

(Sumber: Hasil Output SPSS 25, 2020)

Hasil output dari penelitian yang dilakukan apda PT. Winsen Kencana Perkasa dimana dilakukan pengujian secara simultan maka digunakan uji F. Pengujian dalam penelitian ini telah mampu menunjukkan variabel independen memiliki suatu pengaruh secara simultan terhadap variabel dependen. Selain itu, pada tabel 9 sebagaimana yang telah diperlihatkan memberikan hasil jika perhitungan uji $\mathrm{F}$ yang memiliki $\mathrm{F}$ hitung 44,891 > F tabel 3,07 dan nilai signifikan sebesar 0,000 atau lebih kecil dari 0,05 (F. Sig $0,000<\alpha 0,005$ ), artinya ketiga variabel yang menyatakan bahwa kompensasi dan kepuasan kerja karyawan memiliki suatu pengaruh yang bernilai secara positif dan nilai tersebut merupakan nilai yang signifikan terhadap kinerja karyawan pada PT Winsen Kencana Perkasa diterima.

\section{KESIMPULAN}

Sebagaimana penelitian telah dilakukan hingga pada tahap analisis data dengan judul pengaruh kompensasi dan kepuasan kerja terhadap kinerja karyawan pada PT Winsen Kencana Perkasa, maka ditarik kesimpulan sebagai berikut: (1) Variabel kompensasi berpengaruh signifikan secara parsial terhadap kinerja karyawan pada PT Winsen Kencan Perkasa (2) Variabel kepuasan kerja berpengaruh signifikan secara parsial terhadap kinerja karyawan pada PT Winsen Kencana Perkasa (3) Variabel kompensasi dan kepuasan kerja secara simultan berpengaruh positif dan 
signifikan terhadap kinerja karyawan pada PT Winsen Kencana Perkasa

\section{DAFTAR PUSTAKA}

Adha, S., Wandi, D., \& Yanto Susanto. (2019). Pengaruh Kepuasan Kerja Terhadap Kinerja Pegawai Pada Dinas Perindustrian, Perdagangan Dan ESDM Kabupaten Pandeglang. Ekonomi Vokasi, 2(1), 61-72.

Heryenzus, \& Laia, R. (2018). Pengaruh Kompensasi Dan Motivasi Terhadap Kinerja Karyawan Dengan Kepuasan Karyawan Sebagai Variabel Intervening Pada PT Bank Negara Indonesia Cabang Batam. 6(2), 12-21.

Kilvin, \& Siagian, M. (2020). Pengaruh Disiplin Kerja, Kompensasi Dan Motivasi Terhadap Kinerja Karyawan Pada PT Mitra Sintera Di Kota Batam. Jurnal Ilmiah Manajemen Bisnis Dan Inovasi Universitas Sam Ratulangi, 7(2), 206-219.

Laia, F. N., Umi, F., \& Adi, S. (2019). The Effect of Work Stress, Compensation and Job Satisfaction on Employe Performance at Mojang Nova. Jurnal Ilmiah Bidang Manajemen Dan Bisnis, 2(1), 21-29.

Latief, A., Syanrdiansah, \& Safwan, M. (2019). Pengaruh Komitmen Organisasi Dan Kepuasan Kerja Terhadap Kinerja Karyawan Badan Penyelenggara Jaminan Sosial Kesehatan. Jurnal Administrasi Publik, 9(1), 43-48.

Latief, A., Syardiansah, \& Sarfwan, M. (2019). Pengaruh komitmen organisasi dan kepuasan kerja terhadap kinerja karyawan bpjs kesehatan cabang langsa. Ekonomi, 4(April), 52-65.

Perkasa, D. H., Mariah, \& Ajis, A. (2019). Dampak Pemberian Kompensasi, Kepuasan Kerja Motivasi Dan Pengaruhnya Terhadap Kinerja Karyawan (Studi Pada Karyawan PT Nusantara Infrastructure TBK Jakarta). Jurnal Manajemen, 14(2), 114-126.

Putri, E. novia, \& Ardiana, I. D. K. R. (2019). Pengaruh Motivasi Kerja, Kompetensi, Dan Kompensasi Terhadap Kinerja Tenaga Kependidikan Melalui Kepuasan Kerja Di Lingkungan ITS Surabaya. 03(02), 28-36.

Rohaeni, H. (2016). Pengaruh Pemberdayaan Sumber Daya Manusia Dan Kompensasi Terhadap Kinerja Pegawai Bagian Humas Kanwil Kementerian Agama Propinsi DKI Jakarta. 1(April), 40-52.

Shinta, D., \& Siagian, M. (2020). Pengaruh Komunikasi, Disiplin Kerja, dan Insentif Terhadap Kinerja Karyawan Pada PT Citra Mandiri Distribusindo. E-Jurnal Apresiasi Ekonomi, 8(2), 338-346.

Siagian, M. (2017). Analisis Kompetensi, Kepuasan Kerja Terhadap Kinerja Pegawai Melalui Motivasi Kerja Di Kantor Pelayanan Pajak Daerah (KPPD Batam Dinas Pendapatan Daerah Provinsi Kepulawan Riau). Prodi Manajemen, 5(2), 59-68.

Siagian, M., \& Defrianti. (2018). Pengaruh Gaya Kepemimpinan Dan Kompensasi Terhadap Kinerja Karyawan PT Mega Telekom Di Kota Batam. Jurnal Akuntansi Dan Ekonomika, $8(1), 13-21$.

Siama, H., Herminawati, \& Ruslan, M. (2017). Pengaruh kompensasi terhadap kinerja karyawan pada kantor training center uin alauddin makassar. 3(004), 99-110.

Widyawati, S. R., Adnyana, I. D. M., \& Mustika, I. nyoman. (2019). The Effect of Compensation and Job Promotion on Employee Job Satisfaction at Pt. Permata Jaga Karya. International Journal of Contemporary Research and Review, 10(12), 21683-21692.

Yudha, R. I. (2018). Pengaruh Budaya Organisasi Dan Kepuasan Kerja Terhadap Kinerj Karyawan Pada PT. Jaya Abadi Sumber Pasifik Kota Jambi. Manajemen Dan Kewirausahawan, 9(Mei), 24-35. 